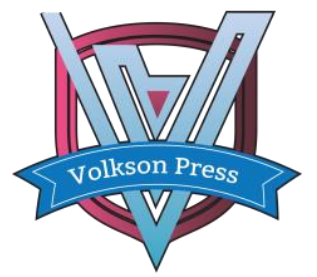

Contents List available at VOLKSON PRESS

Economics \& Management Innovations(EMI)

DOI : http://doi.org/10.26480/icemi.01.2017.144.146

\title{
Analysis and control of accounting firm's audit risk
}

\author{
Chen Junyu ${ }^{{ }^{*}}$ \\ 1Jiangsu Province,Nanjing City, Xuan Wu District,Xiao Ling Wei Road 200,China. \\ *email:542742756@qq.com
}

This is an open access article distributed under the Creative Commons Attribution License, which permits unrestricted use, distribution, and reproduction in any medium, provided the original work is properly cited.

\section{ARTICLE DETAILS}

\section{Article History:}

Received 02 october 2017 Accepted 06 october 2017

Available online 11 october 2017

\section{Keywords:}

Audit risk; risk control; accounting firm.

\section{ABSTRACT}

With more and more attention people paid to quality and the authenticity of the audit report and the audit opinion,it is highly time for auditors and accounting firms to pay attention to the audit risk during the audit progress in case of the negative effect of the credit of accounting firms or even the future development of the audit industry.This paper takes the Securities and Futures Commission of Jilin Authority handle with the audit failure of the Tonghua Grape Wine co.ltd (Tonghua)as an example,do the specific analysis of the status and problems of audit risk the audit firms faced with in the audit process, looking for a reasonable approach to enhance the risk awareness of the firm's awareness from the three aspects of audit,such as audit subject, the audit object and the external environment.The contribution of this paper is to combine the existing recent case in 2016 with specific analysis of audit risk and give the proposal from the three aspects of audit standpoint.

\section{Introduction}

The audit risk is the risk that due to the unknown situation, the auditor cannot judge in the audit process and express an inappropriate audit opinion when the financial statements are materially misstated. As is known to all,Signature auditors should take the relative responsibility. They are faced with the risk such as lose job, bear the corresponding compensation and be accused of impropriety if the enterprise provides uncertain information and auditor did not play its due role of information screening and issuing proper advice.

Table 1 : Commission Disciplinary Action and matters relating to the 2015 issue of Tonghua shares

\begin{tabular}{|c|c|c|c|}
\hline & Net margin & Goodwill & \multirow{6}{*}{\begin{tabular}{l}
\multicolumn{1}{c}{ Matters explanation } \\
On 11th Mar 2015,Tonghua \\
bought $51 \%$ equities of \\
Beijing JiuRunYuan E- \\
commerce Ltd by capital \\
increase and transfer \\
shares. This is a case of \\
corporate mergers under \\
different controls,Tonghua \\
paid 66.69 million for \\
combined price while fair \\
value of the identifiable net \\
lassets of the acquirer's \\
enterprise on the day of \\
merger was 59.89 million.The \\
carrying value of identifiable \\
net assets was 59.89 \\
million.The evaluated value of \\
JiuRunYuan is 135 million \\
y yuan.Tonghua confirmed \\
Goodwill 74.94 million and \\
Non operating income is 2.07 \\
million.
\end{tabular}} \\
\hline $\begin{array}{l}2015 \text { Annual Report } \\
\text { [million yuan] }\end{array}$ & 2.55 & 74.94 & \\
\hline $\begin{array}{c}\text { Difference } \\
\text { [million yuan] }\end{array}$ & 2.07 & 38.79 & \\
\hline $\begin{array}{c}\text { Adjusted } \\
\text { [million yuan] }\end{array}$ & 0.48 & 36.15 & \\
\hline Reasons & $\begin{array}{l}\text { There was an error in } \\
\text { the recognition of the } \\
\text { fair value of } \\
\text { identifiable net assets } \\
\text { instead of operating } \\
\text { revenue, When } \\
\text { merging JiuRunYuan }\end{array}$ & $\begin{array}{l}\text { The difference } \\
\text { between the book } \\
\text { value and the } \\
\text { evaluation value was } \\
\text { recognized as goodwill } \\
\text { mistakenly }\end{array}$ & \\
\hline Penalty Results & $\begin{array}{l}\text { The above transaction } \\
\text { treatment had a vital } \mathrm{i} \\
\text { results of the company } \\
\text { gave the chairman, ch } \\
\text { Secretary of the board } \\
\text { promptly to circulate } \\
\text { auditor Han Bo, Liu Ku }\end{array}$ & $\begin{array}{l}\text { s and accounting } \\
\text { ypact on the operating } \\
\text { y in 2015, The CSRC } \\
\text { ief financial officer, } \\
\text { of directors of company } \\
\text { a notice of criticism; the } \\
\text { un regulatory concerns. }\end{array}$ & \\
\hline
\end{tabular}

Tonghua is just one of these companies who have the audit failure highlighted by China Securities Regulatory Commission(CSRC). Recently,Tonghua was found that the risk of material misstatement exists in the financial statements and there are some mistakes in combined financial statements because auditors don't give due attention to misstatements and leakage.Tonghua shares was observed risks of material misstatement in 2015 annual financial statements, and auditors do not notice net profit and goodwill in the financial statements reasonably, directly make the net profit inflated 2.072 million yuan (accounting for $81.31 \%$ in 2015 annual net profit), overstated goodwill 38.79 million (accounting for $51.76 \%$ in 2015 annual net profit).The Supervision Department One of Shanghai Stock Exchange issued a regulation that make the auditors who served Tonghua under supervision, as shown in table 1.So some enterprise merger occurs, financial statements maybe have the risk of material misstatement.Once the company was checked to be found to have the risk of material misstatement, the Commission will make the disposition of company executives .Only do auditors perceive prudently the audit risk can they avoid the danger of supervision and punishment.

\section{Causes of audit risk of accounting firms}

\subsection{Cause of Audit subject}

\subsubsection{Preparation in advance is inadequate}

Auditors should confirm the customer's going concern ability fully and distinguish the risky customers who have the high financial risk and high management risk, so that they can make a correct decision to sign the audit engagement letter,in order to avoid yourself in a passive situation.There are many factors that will affect the audit report and customer audit result,such as the perfect degree of internal control of the audited entity, excessive pursuit of economic interests to ignore the development of the whole company, the update of accounting policies. Prior to the audit, auditors should confirm that the important information is not omitted in case of trouble. As an illustration,when auditors do bank deposit audit in Tonghua shares,they cannot find out the difference in bank's name between the Bank savings balance and the List of other bank accounts opened,making the auditor ignore Agricultural Bank of China's bank account which already exists, moreover they did not carry out confirmation on the account,resulting in the failure of audit result of the bank deposits.

\subsubsection{Lack of professional competence and professional} ethics

When an accounting firm cooperate with the large size of the entity, the audit project requires a large number of auditors, the inexperienced and unprofessional auditor will make different conclusions on the financial situation, which may affect the auditors occupation judgment. In the premise of ensuring that auditors are able to complete the audit report with high quality and efficiency in time, the auditor has good professional skills to judge the audit risk, identify the risk of material misstatement in the project reasonably.Tonghua shares was discovered many issues,their accounts receivable in the annual audit was inconsistent with accounting policy; they did not disclose the specific revenue recognition policy; some items were not disclosure. the audit report issued by the auditor also make 
people question whether the firm pursuits the number of customers resulting in reducing the number of audit evidence required which improved the inspection risk,ignoring the quality of audit project, or auditors themselves lack of the ability to finish the audit project. Whether the accounting firm ignores the audit staff training due to undertake too much business exerts an influence on the audit quality.

\subsubsection{The quality control system of the general and branch office is inconsistent}

With the growth of the scale, the coordination and management system between the branches and the general is different.The general office cannot monitor and constraint all of the branches all the time in the business culture and even the management of risk,the ability to control risk for the general has declined.The firms have different measures to risk control, some of them choose to set up risk control departments specially to verify the audit risk.However, if there is difference in audit risk criteria for risk control personnel to check between the general office and the brunches, the audit report may be different possibly.Normally,the general office has more advantage in number of business orders with experienced and competent Certified Public Accountants (CPA) than brunches.

\subsection{Factors of audit object risk}

\subsubsection{The inherent risk of the audited entity is high}

In order to pursue their own interests, the management of enterprises will have the motivation to manipulate accounting profits and whitewash financial statements or when customers fall into the financial crisis, they may have a problem with going concern , the executives have no choice but to use clever means to color financial accounts by using accounting policy in order to bring great profits for themselves in the book, which makes accounting firms rush into unknown audit risk. Once the audited units eventually go bankrupt because of poor management, creditors and stakeholders will blame firms and auditors, especially under the condition of standard unqualified opinion issued by the registered accountants. Auditors failed to find the material misstatement risk in Tonghua shares 2015 annual audit report,made a mistake in combined balance sheet,which caused part of the company's executives were punished and auditors would be given regulatory attention.

\subsubsection{Independence is affected}

Some people lack of strong sense of responsibility and strict audit staff occupation attitudes may be in pursuit of personal interests,and give up the practice guidelines,leading to the audit failure. Auditors are in violation of occupation morality is not only that auditors take bribe from the entity, but also fail to maintain the independence in the audit program .If they are not in accordance with the audit industry standard requirements, the accounting report issued will unauthentic and incomplete which will have a negative impact.

\subsection{Causes of audit risk of external environment}

\subsubsection{High Competition pressure between firms}

With the number of accounting firms presented a huge growth over the years,there are 8462 accounting firms ending April,2017 and 734 of them were registered in Beijing.The Chinese Institute of Certified Public Accountants has issued a report concerning a comprehensive evaluation of the TOP 100 accounting firm's information in 2016.According to the report we can find that 49 of them have the business income more than 100 million and 6 of them acquire the income over 20 billion,which can illustrate that the competitive pressure among the firms is particularly great. Among the companies whose business income is more than 100 million,the CPA average annual salary is from 558.2 thousand to 3.9 million yuan.As shown in Table 2,the salary of BIG 4's CPA is higher than the auditors in local firms which is a clear gap.Although some local accounting firms have the advantage of price, large state-owned enterprises and foreign-funded enterprises of the audit business was undertaken by BIG4, the low audit fees can not guarantee the quality of work.If the audited units and the firm finally can not reach a unified understanding, the audited entity may change the firm.In the audit market oversupply situation, in order to complete more business income the audit staff in the face of the unreasonable demands from the auditee may tend to compromise and select issued unqualified audit reports, bringing the level of audit quality and even the whole industry down.

Table 2:top 10 of 2016 business revenue of the Certified Public Accountant Firms(CPA Firms)

\begin{tabular}{ccccc}
\hline $\begin{array}{c}\text { Ran } \\
\mathrm{k}\end{array}$ & $\begin{array}{c}\text { The accounting firm } \\
\text { name }\end{array}$ & $\begin{array}{c}\text { Business } \\
\text { income } \\
\text { (billion) }\end{array}$ & $\begin{array}{c}\text { Number of } \\
\text { CPAs }\end{array}$ & $\begin{array}{c}\text { Average business } \\
\text { income of CPAs } \\
\text { ( million })\end{array}$ \\
\hline 1 & PWC China & 41.17 & 1056 & 3.90 \\
2 & RUIHUA CPA firm & 40.30 & 2514 & 1.60 \\
3 & Shulun pan CPA firm & 35.02 & 1939 & 1.81 \\
4 & Deloitte China & 33.25 & 852 & 3.90 \\
5 & Ernst \& Young China & 29.61 & 999 & 2.96 \\
6 & KPMG China & 25.33 & 741 & 3.42 \\
7 & Pan-China CPA firm & 19.28 & 1453 & 1.33 \\
8 & Dahua CPA firm & 15.75 & 1114 & 1.41 \\
9 & Share Wing CPA firm & 15.61 & 1278 & 1.22 \\
10 & Grant Thornton CPA & 15.29 & 949 & 1.61 \\
\hline
\end{tabular}

\subsubsection{Regulators are not strict}

If the company want to be listed, the CSRC is not alone in its concerns about Initial public offerings

(IPO) quality control,the quality of report can influence the result of IPO directly,the company's audit report unqualified will be directly related to the accounting firm's reputation.For the listed companies and accounting firms who have the trend of violations, if the violation cost is too low and the actual income is large,they will make the conducive selection for their own interests, and ignore the relevant provisions of audit risk and the firm's audit quality control.

\subsubsection{The judgment of responsibility is determined differently}

There is also a difference between the CPA profession and the legal profession in determining the audit responsibility.In general, the CPA profession only requires the audit process in accordance with laws and regulations,and audit report is written just according to Information provided by the audited entity which is seen to be in line with the law.Therefore, the credibility of audit evidence should be checked during the audit process because in most cases, the audit process is not able to ensure that the materials provided by the audited entity must be true. But legal profession deem that the authenticity of the audit results is the most important.If the audit report has false content and make investors property loss,the accounting firms and certified public accountants have the suspect to fraud, which make them have to bear the loss.

\section{Audit risk control measures}

\subsection{Measures of Audit subject risk}

\subsubsection{Do the audit communication effectively in the early stage}

The level of overall audit stuff $\mathrm{n}$ our country at present should be improved the key of this is to improve the ability of the audit plan, identify and assess the risk of material misstatement. Signing audit engagement letter should be based on doing the preparatory work and assessing the risk of material misstatement carefully to develop effective audit plan and complete the audit task effectively which takes the necessary cost and effort to understand customers and their environment, for identification and assessment of accounting statements misstatement of the company itself Faced with the company with high risk,auditors need to make cautious and rational evaluation of the company.when they must make judgment whether to undertake business, they should consider reasonably, if the audit communication can not go well effectively in the early stage,the company should learn to refuse.In the audit process, if it is the first year the firm has business with the audited units, the firm must know detail the business line and the overall development of the industry through a lot of information.

\subsubsection{Improve professional competence and occupation}

The key point of improving the overall level of auditors is to improve the ability of the audit plan, identify and assess the risk of material misstatement.The firm can make arrangement of internal meeting for communication,encourage the experienced staff to share the experience with the green hand who engaged in audit work lately,combined with the existing case to learn to identify material risk in financial statements and analyze how to make the audit risk within the acceptable level through the audit procedures. The auditor should do more research and in-depth discussion about Accounting Standards for Business Enterprises and Dependent audit principle to avoid the mistake making the net profit 
inflated shown in the Tonghua audit to prevent the untrue report from misleading investors. But the training is not only about the professional skill, but also should pay more attention on the occupation responsibility specially. To complete the follow-up education, the firm can invite specialists participate in the organization of lectures or training of professional quality, but also make auditors feel the importance of knowing the law in the solemn atmosphere throughout the publicity. The accounting firm's business involves many areas of construction such as chemical, pharmaceutical, real estate,so some auditors need to have relevant knowledge background to support him to do the occupation judgment reasonably.

\subsubsection{Improve the quality control system}

The accounting firm should establish their own risk prevention and control system which is related to the salary,performance and quality to guarantee quality when they finish their working paper and all audit reports.The team should have a leader who will mainly to bear the risk and make auditors responsible for every audit projects directly, and reward them according to risk and labor hours. The accounting firms expand their business and open a new branch through the recruitment of new employees in the local area. The headquarters can provide financial, human resources and support, send senior staff to give guidance to effectively improve the system to control the accounting firm internal audit risk.the branch should do the system construction involves in aspects such as financial audit, management and inspection in order to restrict and regulate the accounting firm audit activities. The accounting firm also should establish accountability system,which is not just for signature Accountants, but also to investigate the specific accounting responsibility of Certified public accountants to improve the accounting firm audit, assessment, evaluation and management mechanism constantly .

\subsubsection{Cultivate independence}

The audit service market rules is the first for auditors to get rid of the audit business activities in a weak position to prevent them from being restricted by the customer in order to objectively make the audit judgment and issue the audit report truly and independently in audit activities.In view of audit fees which the audit unit would pay, the audit unit could enjoy the initiative to some extent, so when the project manager and the audited company sign the engagement letter, the audited company should be preferred to pay $30 \%-50 \%$ audit fees to ensure the independence and objectivity of the CPA audit.

\subsection{Measures of Audit external risk}

\subsubsection{Face competition in the same industry actively}

The improper price competition of CPA firms has a negative impact on the industry,so before undertaking business, we must rationally consider the consumption of manpower and material resources to ensure of the quality of audit.When the accounting firms and the audit unit can not reach an agreement on something, some accounting firms were made to withdraw from the company, while some small accounting firms may abandon their standards for more earnings.According to the current situation that audit market has too many small firms and price competition, firms should be encouraged to joint to become large and medium-sized, after the merger of accounting firms can choose to give up some high risk customers.

\subsubsection{Strengthen the supervision}

The Ministry of finance,the CSRC,the AICPA and other state organizations should take regular or irregular inspection of the business of accounting firm, combined with the economic development of different regions, development status of the company, enterprise scale, the development situation of the industry to determine the reasonable charges, and the department concerned should increase the supervision on the company whose fees is too low or too high.If there is some conclusive evidence to clarify that audit failure is caused by certified public accountants or accounting firms,the department concerned should increase punishment of the CPA and CPA for their responsibility.In the audit process through Portuguese shares auditors did not disclose a series of audit failure such as the accounts receivable in this period, recovered or reversed bad debts, the CPA should do the self-examination in the role of audit process,and accepted corresponding punishment for themselves. The accounting firm who failed to do its duty seriously should be given administrative penalties and suspend the audit engagements, submit relevant written rectification plan to the Ministry of finance and the Commission.When strengthened the social supervision at the same time, the accounting firm can check crossly and do the regular inspection and supervision for the audit personnel to abide by the occupation morals.The purpose of this can not only improve the level and quality of audit work, but also benefit to audit risk prevention for the audit staff.

\subsubsection{Improve the related laws}

The public should supervise the audit quality in the process of audit,also should observe whether the laws and regulations are reasonable. To constantly improve the laws and regulations of the audit, a series of laws and regulations should be published to support firm arrangements for follow-up study. When determining the responsibility for auditing major projects,the stuff can be equipped with professional advisers as a consultant to develop multi criteria according to audit hours and ability to determine the audit responsibility not just because of audit result.To determine the final audit fees in accordance with the factors of time and workload of the audited entity can also prevent some firms by reducing the fees far below the industry fee standard to recruit customers which promote the firm competitive fairness and transparency.

\section{Conclusion}

With the development of economy, the risk factors in the audit process is more complex, auditors should have the causes of the risk of a comprehensive understanding in order to prevent audit risk better. The accounting firm as the supervisor should investigate the risk factors of audit body, audit object and audit external environment clearly to issue the audit report more authentic and complete. Auditors must pay attention to the audit risk which may be produced from economic activities probably and reduce the audit risk effectively, control and avoid the audit risk reasonably, improve the quality of the audit report, improve the the credibility of CPA ,considering integrity of the image of the accounting firm to give the public and investors with the most credible audit information.

\section{References}

[1] AICPA: Statement on auditing standards NO.47:Audit Risk and Materiality in Conducting and Audit,(1983)

[2] AICPA: AICPA Professional Standards.Chicago: Commerce Clearing House,(1988).

[3] Dusenbury., Reimers, J.L., Wheeler, S.W.The audit risk model: an empirical test for conditioned dependencies among assessed component risk, Auditing,(2000).

[4] Crawford,M.and Stein, W.Auditing risk management :find in theory but who can do it in practice? , International Journal of Auditing, (2000).

http://www.cicpa.org.cn/news/201701/t20170112_49462.html

[6] Lin Xiuhan.Research on Factors Influencing Audit Quality of accounting firms, Finance and Tax,(2016).

[7] Song Yanheng,Xiao Xing.Regulatory risk, Firm size and Audit quality, Asian social science,(2012).

[8] Wally Smieliauskas,Jiang Yijun,Chen Wei.Audit evidence and Audit risk.Journal of Nanjing Audit University.(2013)

[9] Mian Xing.Study on the Avoidance Measures of the Audit Risk of Project Item.Asian Social Science(2010)

[10] Dany Julien,Sacha Sabin.A risk-based method for audit site selection.International Journal of Government Auditing.(2012)

[11] Liu Jie .The enterprise risk management and the risk oriented internal audit.iBusiness.(2012) 